\title{
Studi Pustaka: Pengaruh Perhatian Orang Tua Terhadap Prestasi Belajar Siswa Di Sekolah
}

\author{
Safitri $^{1}$, Nurhayati ${ }^{2}$ \\ STKIP Singkawang \\ shafitrysasa@gmail.com ${ }^{1}$, nurhayati@ stkipsingkawang.ac.id ${ }^{2}$
}

\section{Keywords :}

Perhatian orang tua, prestasi belajar

\begin{abstract}
Penelitian ini di latarbelakangi oleh pentingnya faktor keluarga khususnya perhatian orang tua untuk meningkatkan prestasi belajar siswa di sekolah. Penelitian ini bertujuan untuk mengetahui pengaruh perhatian orang tua terhadap prestasi belajar. Jenis penelitian adalah studi pustaka. Studi pustaka yang dilakukan adalah studi pustaka terhadap jurnal, artikel, skripsi ataupun tesis hasil penelitian. Hasil penelitian ini didapatkan bahwa perhatian orang tua berpengaruh sangat kuat terhadap prestasi belajar siswa dari sisi psikologis anak..
\end{abstract}

\section{PENDAHULUAN}

Salah satu cara untuk mengukur apakah pembelajaran yang sudah dilaksanakan di suatu kelas berhasil atau tidak adalah dengan melihat prestasi belajar siswa. Menurut Nitko (2011) prestasi belajar adalah pengetahuan, kecapakan, keahlian yang berkembang pada seorang siswa sebagai hasil dari pembelajaran. Ahmadi \& Widodo (2004) mengemukakan bahwa prestasi belajar yang dicapai seseorang merupakan hasil interaksi berbagai faktor yang mempengaruhinya (pendidikan formal), dan pendidikan di dalam masyarakat (pendidikan non formal). Oleh karena itu pendidikan bukan hanya menjadi tugas guru dan sekolah saja tetapi juga tugas bagi orang tua. Orang tua pasti menginginkan anaknya memiliki prestasi belajar yang baik. Prestasi belajar merupakan indikator untuk mengukur keberhasilan proses pembelajaran. Tinggi rendahnya prestasi belajar siswa dipengaruhi oleh faktorfaktor yang berasal dari dalam dan luar siswa itu sendiri.

Nasution (Djmarah, 2002) menyebutkan faktor eksternal yang mempengaruhi prestasi belajar meliputi: lingkungan alam, lingkungan sosial budaya, kurikulum, program, sarana dan fasilitas, dan guru. Sedangkan faktor internal meliputi : kondisi psikologis (minat, kecerdasan, bakat, motivasi, kemampuan kognitif) dan fisiologi (kondisi fisik dan kondisi panca indra). Perhatian orang tua ini sangat penting bagi anak dalam kegiatan belajarnya. Slameto (2010) berpendapat bahwa dalam lingkungan keluarga, perhatian orang tua dalam belajar anak sangat berpengaruh terhadap prestasi belajar anak tersebut.

Perhatian orang tua memberikan dampak yang baik bagi anak seperti meningkatkan semangat dan motivasi belajar bagi anak. Perhatian dan bimbingan orang tua di rumah akan mempengaruhi kesiapan belajar siswa, baik belajar di rumah maupun di sekolah. Perhatian yang diberikan oleh orang tua terhadap anak dapat memotivasi siswa dalam melakukan kegiatannya, termasuk memotivasi anak untuk belajar. Bagi siswa motivasi ini sangat penting karena dapat menggerakkan perilaku siswa ke 
arah yang positif sehingga mampu menghadapi segala tuntutan, dan kesulitan dalam belajar (Faturrohman, 2017).

Prestasi belajar tidak hanya dipengaruhi oleh kegiatan pembelajaran di sekolah, namun juga dipengaruhi oleh lingkungan sekitar. Lingkungan sekitar yang dapat mempengaruhi hasil beajar salah satunya yaitu keluarga, terutama orang tua. Orang tua yang kurang atau tidak memperhatikan pendidikan anaknya dapat menyebabkan anak kurang berhasil dalam belajarnya (Rismawati, 2015). Usia SD (6 sampai 10/12 tahun) dianggap sebagai usia yang menyulitkan, tidak rapi, suka bertengkar, usia berkelompok dan usia penyesuaian diri. Masa ini juga dikatakan sebagai periode kritis dalam dorongan berprestasi yaitu masa dimana anak membentuk kebiasaan untuk mencapai sukses, sangat sukses, atau tidak sukses. Sehingga dalam masa ini perhatian orang tua sangatlah diperlukan untuk mendukung keberhasilan anak (Rismawati, 2015).

\section{DISKUSI}

Keluarga merupakan lembaga sosial paling kecil dan tempat manusia berinteraksi untuk yang pertama kali sebagai makhluk sosial. Dalam lingkungan keluarga, peran orang tua sangat penting dalam pembentukan karakter, kecerdasan anak, penanaman nilai, norma, dan budaya yang ada dalam masyarakat. Keluarga juga merupakan pusat pendidikan yang utama dan pertama bagi seorang anak sebelum memperoleh pendidikan formal di sekolah (Fathurrohman, 2017). Menurut Ki Hajar Dewantara (Rohman, 2009) proses pendidikan dapat terjadi dalam tiga lingkungan pendidikan yaitu pendidikan di dalam keluarga (pendidikan informal), pendidikan di dalam sekolah (pendidikan formal), dan pendidikan di dalam masyarakat (pendidikan non formal). Oleh karena itu pendidikan bukan hanya menjadi tugas guru dan sekolah saja tetapi juga tugas bagi orang tua. Orang tua pasti menginginkan anaknya memiliki prestasi belajar yang baik. Prestasi belajar merupakan indikator untuk mengukur keberhasilan proses pembelajaran. Tinggi rendahnya prestasi belajar siswa dipengaruhi oleh faktor-faktor yang berasal dari dalam dan luar siswa itu sendiri.

Nasution (Djmarah, 2002:143) menyebutkan faktor eksternal yang mempengaruhi prestasi belajar meliputi : lingkungan alam, lingkungan sosial budaya, kurikulum, program, sarana dan fasilitas, dan guru. Sedangkan faktor internal meliputi : kondisi psikologis (minat, kecerdasan, bakat, motivasi, kemampuan kognitif) dan fisiologi (kondisi fisik dan kondisi panca indra).

Sekolah mempunyai kemampuan yang terbatas, mempunyai waktu yang terbatas dan sekolah bukan menjamin segala-galanya menjadi beres. Disini peran orang tua dengan sendirinya menjadi pendidik atau pengajar bagi anaknya di rumah. Di rumah anak memiliki banyak kesempatan untuk 6 belajar bila dibandingkan dengan di sekolah (Yusmanto, 2014).

Perhatian dari orang tua sangat membantu anak dalam peningkatan belajar di rumah maupun di sekolah, juga bermanfaat bagi perkembangan psikologis anak. Perhatian orang tua dapat berwujud tersedianya sarana dan prasarana belajar yang menjadikan anak lebih bersemangat dalam menjalankan aktivitas belajarnya. Selain itu menegur anak jika melakukan hal-hal yang kurang baik (melanggar norma-norma yang berlaku), dengan disertai suatu arahan dan bimbingan kepada anak, sehingga anak menjadi baik (Yusmanto, 2014).

Orang tua yang kurang atau tidak memperhatikan pendidikan anaknya, misalnya; mereka acuh tak acuh terhadap belajar anaknya, tidak memperhatikan akan kepentingankepentingan dan kebutuhan-kebutuhan anaknya dalam belajar, tidak mengatur waktu belajarnya, tidak memperhatikan apakah anak belajar atau tidak, tidak mau tahu bagaimanakah kemajuan belajar anaknya, kesulitan-kesulitan yang dialami dalam belajar dan lain-lain, yang dapat 
menyebabkan anak tidak/ kurang berhasil dalam belajarnya (Yusmanto, 2014).

Perhatian orang tua memiliki pengaruh psikologis yang kuat dalam kegiatan belajar anak. Anak cenderung akan giat dan sungguh-sungguh dalam belajar karena merasa diperhatikan oleh orang tuanya. Sehingga dapat dikatakan bahwa kurang maksimalnya hasil belajar yang dicapai siswa, diduga karena dipengaruhi oleh kurangnya perhatian orang tua terhadap kegiatan belajar anak di rumah (Rismawati, 2015).

Perhatian adalah pemusatan tenaga psikis yang tertuju pada suatu objek yang datang dari dalam dan luar individu. Perhatian orang tua memiliki pengaruh psikologis yang kuat dalam kegiatan belajar anak. Anak cenderung akan giat dan sungguh-sungguh dalam belajar karena merasa diperhatikan dan dianggap penting oleh orang tuanya. Dengan perhatian yang diberikan orang tua maka anak akan merasa bahwa keberhasilannya dalam belajar tidak hanya untuk dirinya namun diharapkan juga oleh orang tuanya (Rismawati, 2015). Menurut Sardiman (2007) Peran orang tua dalam belajar anak seharusnya dapat membimbing belajar anaknya, membimbing dalam pekerjaan rumahnya, memotivasi belajar anaknya, sehingga orang tua dapat memantau perkembangan belajar anaknya.

\section{KESIMPULAN}

Perhatian orang tua memiliki pengaruh psikologis yang kuat dalam kegiatan belajar anak. Peran orang tua dalam belajar anak dapat membimbig anaknya dalam pekerjaan rumahnya, dalam memotivasi belajar anaknya, dalam memantau perkembangan belajar anaknya. Ketika seorang anak mendapatkan perhatian penuh dari orang tuanya dalam belajar, anak cenderung akan giat dan sungguh-sungguh dalam belajarnya. Sehingga hal tersebut dapat berpengaruh kepada prestasi belajarnya.

\section{REFERENSI}

Ahmadi, A. \& Widodo. (2004). Psikologi Belajar. Jakarta: PT Rineka Cipta.

Djamarah, S.B. (2002). Psikologi Belajar. Jakarta: Rajawali Pers.

Fathurrohman, M.T. (2017). Pengaruh Perhatian Orang Tua Terhadap Prestasi Belajar Siswa Kelas V. Jurnal Pendidikan Guru Sekolah Dasar, 10(6), 975-982.

Nitko, A.J., \& Brokhart, S. M. (2011). Educational assessment of students (6th ed.). Boston: Allyn \& Bacon.

Rismawati, K. (2015). Pengaruh Perhatian Orang Tua dalam Kegiatan Belajar terhadap Hasil Belajar Siswa Kelas IV Sekolah Dasar Daerah Binaan III Kecamatan Kandangserang Kabupaten Pekalongan. Semarang: Universitas Negeri Semarang.

Rohman, A. (2009). Memahami Pendidikan \& Ilmu Pendidikan. Yogyakarta: LaksBang Mediatama Yogyakarta. Arif Rohman. (2009). Memahami Pendidikan \& Ilmu Pendidikan. Yogyakarta: LaksBang Mediatama Yogyakarta.

Sardiman A.M. (2007). Interaksi dan Motivasi Belajar Mengajar. Jakarta: PT Raja Grafindo Persada.

Slameto. (2010). Belajar dan Faktor-faktor yang Mempengaruhinya. Jakarta: Rineka Cipta. 
Journal of Educational Review and Research

Vol. 1 No. 2, December 2018: $64-67$

e-ISSN: 2597-9760, p-ISSN: 2597-9752

Yusmanto, B. (2014). Pengaruh Perhatian Orang Tua Terhadap Hasil Belajar Membaca Al-Qur'an Siswa Kelas VIII MTs NU 17 Kyai Jogoreso Kendal Tahun Pelajaran 2013/2014. Semarang: IAIN Walisongo Semarang. 